\title{
Archaea and Bacteria Acclimate to High Total Ammonia in a Methanogenic Reactor Treating Swine Waste
}

\author{
Sofia Esquivel-Elizondo, ${ }^{1,2}$ Prathap Parameswaran, ${ }^{3}$ Anca G. Delgado, ${ }^{1} J^{\prime a n}$ Maldonado, \\ Bruce E. Rittmann, ${ }^{1,2}$ and Rosa Krajmalnik-Brown ${ }^{1,2}$ \\ ${ }^{1}$ Swette Center for Environmental Biotechnology, The Biodesign Institute, Arizona State University, P.O. Box 875701, \\ Tempe, AZ 85287-5701, USA \\ ${ }^{2}$ School of Sustainable Engineering and the Built Environment, Arizona State University, Tempe, AZ, USA \\ ${ }^{3}$ Department of Civil Engineering, Kansas State University, 2118 Fiedler Hall, Manhattan, KS 66506, USA \\ Correspondence should be addressed to Rosa Krajmalnik-Brown; dr.rosy@asu.edu
}

Received 10 June 2016; Accepted 11 August 2016

Academic Editor: Jessica A. Smith

Copyright (C) 2016 Sofia Esquivel-Elizondo et al. This is an open access article distributed under the Creative Commons Attribution License, which permits unrestricted use, distribution, and reproduction in any medium, provided the original work is properly cited.

\begin{abstract}
Inhibition by ammonium at concentrations above $1000 \mathrm{mgN} / \mathrm{L}$ is known to harm the methanogenesis phase of anaerobic digestion. We anaerobically digested swine waste and achieved steady state COD-removal efficiency of around 52\% with no fatty-acid or $\mathrm{H}_{2}$ accumulation. As the anaerobic microbial community adapted to the gradual increase of total ammonia- $\mathrm{N}\left(\mathrm{NH}_{3}-\mathrm{N}\right)$ from $890 \pm 295$ to $2040 \pm 30 \mathrm{mg} / \mathrm{L}$, the Bacterial and Archaeal communities became less diverse. Phylotypes most closely related to hydrogenotrophic Methanoculleus (36.4\%) and Methanobrevibacter (11.6\%), along with acetoclastic Methanosaeta (29.3\%), became the most abundant Archaeal sequences during acclimation. This was accompanied by a sharp increase in the relative abundances of phylotypes most closely related to acetogens and fatty-acid producers (Clostridium, Coprococcus, and Sphaerochaeta) and syntrophic fatty-acid Bacteria (Syntrophomonas, Clostridium, Clostridiaceae species, and Cloacamonaceae species) that have metabolic capabilities for butyrate and propionate fermentation, as well as for reverse acetogenesis. Our results provide evidence countering a prevailing theory that acetoclastic methanogens are selectively inhibited when the total ammonia- $\mathrm{N}$ concentration is greater than $\sim 1000 \mathrm{mgN} / \mathrm{L}$. Instead, acetoclastic and hydrogenotrophic methanogens coexisted in the presence of total ammonia-N of $\sim 2000 \mathrm{mgN} / \mathrm{L}$ by establishing syntrophic relationships with fatty-acid fermenters, as well as homoacetogens able to carry out forward and reverse acetogenesis.
\end{abstract}

\section{Introduction}

Animal wastes contribute more than half of the biomassbased wastes generated in the United States [1,2]. The organic carbon in animal wastes could be a major source of renewable energy if it were captured as methane gas. Many animal wastes, including swine waste, also are rich in organic nitrogen $(\mathrm{N})$ due to the high protein content in the animals' diet. Anaerobic hydrolysis and fermentation convert the organic $\mathrm{N}$ into ammonia- $\mathrm{N}\left(\mathrm{NH}_{3}-\mathrm{N}\right)$. While typical $\mathrm{NH}_{3}-\mathrm{N}$ (i.e., unionized $\mathrm{NH}_{3}$ and $\mathrm{NH}_{4}^{+}$) concentrations in anaerobic digesters treating domestic wastewater sludge are $650-1100 \mathrm{mg} \mathrm{L}^{-1}$ [3], concentrations in swine manure are as high as $8000 \mathrm{mg} \mathrm{L}^{-1}$ [4-6]. A challenge arises for treating these wastes (and ultimately capturing the organic carbon as energy source) as
$\mathrm{NH}_{3}-\mathrm{N}$ above $1000 \mathrm{mg} \mathrm{L}^{-1}$ is toxic to many groups of microorganisms $[7,8]$, including methanogenic Archaea $[9,10]$.

In anaerobic systems without inhibition by $\mathrm{NH}_{3}-\mathrm{N}$, organic acids produced from acidogenesis are fermented to acetate and $\mathrm{H}_{2}$, and the typical distribution of the electron flow to methane is $67 \%$ through acetate and $33 \%$ through $\mathrm{H}_{2}$ $[11,12]$. Correspondingly, acetoclastic methanogens usually predominate in anaerobic digesters with $<1000 \mathrm{mg} \mathrm{NH}_{3}$ $\mathrm{N} \mathrm{L}^{-1}[13,14]$. In contrast, the vast majority of studies on methanogenesis from swine waste report that the dominant methanogenesis pathway switches from acetoclastic to hydrogenotrophic. Several studies [15-19] reported that the methane production in anaerobic reactors treating wastes with high $\mathrm{NH}_{3}-\mathrm{N}$ occurs mainly via hydrogenotrophic 
TABLE 1: Stoichiometry and thermodynamics of syntrophic acetate, propionate, and butyrate fermentation.

\begin{tabular}{|c|c|c|}
\hline Acetate fermentation & (1a) $\mathrm{CH}_{3} \mathrm{COO}^{-}+\mathrm{H}^{+}+2 \mathrm{H}_{2} \mathrm{O} \rightarrow 2 \mathrm{CO}_{2}+4 \mathrm{H}_{2}$ & $\Delta G^{\prime \prime}=+55.0$ \\
\hline Propionate fermentation & (lb) $\mathrm{C}_{3} \mathrm{H}_{5} \mathrm{OO}^{-}+2 \mathrm{H}_{2} \mathrm{O} \rightarrow \mathrm{CH}_{3} \mathrm{COO}^{-}+\mathrm{CO}_{2}+3 \mathrm{H}_{2}$ & $\Delta G^{\circ \prime}=+76.0$ \\
\hline Butyrate fermentation & (1c) $\mathrm{C}_{4} \mathrm{H}_{7} \mathrm{OO}^{-}+2 \mathrm{H}_{2} \mathrm{O} \rightarrow 2 \mathrm{CH}_{3} \mathrm{COO}^{-}+\mathrm{H}^{+}+2 \mathrm{H}_{2}$ & $\Delta G^{\circ \prime}=+48.3$ \\
\hline Hydrogen oxidation & (2) $4 \mathrm{H}_{2}+\mathrm{CO}_{2} \rightarrow \mathrm{CH}_{4}+2 \mathrm{H}_{2} \mathrm{O}$ & $\Delta G^{\circ \prime}=-130.8$ \\
\hline$(1 \mathrm{a})+(2)$ & (3) $\mathrm{CH}_{3} \mathrm{COO}^{-}+\mathrm{H}^{+} \rightarrow \mathrm{CO}_{2}+\mathrm{CH}_{4}$ & $\Delta G^{\circ \prime}=-75.8$ \\
\hline$(1 b)+(2)$ & (4) $\mathrm{C}_{3} \mathrm{H}_{5} \mathrm{OO}^{-}+(1 / 2) \mathrm{H}_{2} \mathrm{O} \rightarrow \mathrm{CH}_{3} \mathrm{OO}^{-}+(3 / 4) \mathrm{CH}_{4}+(1 / 4) \mathrm{CO}_{2}$ & $\Delta G^{\circ \prime}=-28.0$ \\
\hline$(1 c)+(2)$ & (5) $\mathrm{C}_{4} \mathrm{H}_{7} \mathrm{OO}^{-}+2 \mathrm{H}_{2}+\mathrm{CO}_{2} \rightarrow 2 \mathrm{CH}_{3} \mathrm{COO}^{-}+\mathrm{H}^{+}+\mathrm{CH}_{4}$ & $\Delta G^{\circ \prime}=-42.6$ \\
\hline
\end{tabular}

The standard free enthalpies of formation $\left(\Delta G^{\circ}\right)$ are reported in $\mathrm{kJ}$ reaction ${ }^{-1}$ at $1 \mathrm{M}, \mathrm{pH} 7$, and $25^{\circ} \mathrm{C}$.

methanogenesis, since acetoclastic methanogens are inhibited and washed out. The loss of acetoclastic methanogens in the bioreactors raises questions about the fate of acetate generated by fermentation. It was previously postulated that the loss of acetoclastic methanogens was compensated by syntrophic "acetate oxidation" to $\mathrm{CO}_{2}$ and $\mathrm{H}_{2}$ (more accurately termed reverse acetogenesis) coupled with hydrogenotrophic methanogenesis [20]. Specifically, acetate generated by fermentation is converted into $\mathrm{H}_{2}$ and $\mathrm{CO}_{2}$ by reverse acetogenesis, and the $\mathrm{H}_{2}$ and $\mathrm{CO}_{2}$ are utilized by hydrogenotrophic methanogenesis. The reactions involved in the syntrophy of reverse acetogenesis coupled with $\mathrm{H}_{2}$ conversion into methane with their corresponding $\Delta G^{\circ \prime}$ are illustrated in Table 1, equations (1a) and (2), respectively. Reverse acetogenesis might not be the only mechanism that allows acetate conversion into methane when treating high-ammonium wastes. Methanogenesis is possible if some acetoclastic methanogens are able to adapt to high-ammonium concentrations and avoid being washed out. In fact, Westerholm et al. detected acetoclastic methanogens in methanogenic reactors operating at increasing $\mathrm{NH}_{3}-\mathrm{N}$ concentrations (from 800 to $6900 \mathrm{mg} \mathrm{L}^{-1}$ ) [21]. Thus, an acclimation period may be crucial for developing a microbial community that has acetoclastic methanogens capable of tolerating high $\mathrm{NH}_{3}-\mathrm{N}$.

Another key aspect of microbial community acclimation is the scavenging of $\mathrm{H}_{2}$ produced in fermentation and reverse acetogenesis. It is well known that fermentation of propionate (equation (1b) in Table 1) and butyrate (equation (1c)) is coupled with hydrogenotrophic methanogenesis [22-24]. The highly endergonic nature of these fatty-acid fermentation instances means that they can occur only at very low partial pressures of $\mathrm{H}_{2}\left(<10^{-4}\right.$ atm), which requires a tight syntrophic partnership with a $\mathrm{H}_{2}$ scavenger, such as a hydrogenotrophic methanogen, to maintain a negative $\Delta G^{\circ}$ for fermentation to proceed [25].

The microbial ecology of anaerobic reactors treating high $\mathrm{NH}_{3}-\mathrm{N}$ wastes has received limited attention [15, 2628], and the possible syntrophies among different Archaea, fermenting Bacteria, and homoacetogens are yet poorly understood. High-throughput sequencing in combination with statistical analysis can illuminate microbial dynamics with high $\mathrm{NH}_{3}-\mathrm{N}$ concentrations by identifying key Archaea and Bacteria involved in syntrophic fatty-acid conversion into methane. In this study, we used high-throughput sequencing, parametric correlation, and qPCR (quantitative polymerase chain reaction) to analyze shifts in the Archaeal and Bacterial communities during the startup phase (first 105 days) of an anaerobic digester successfully treating swine manure to generate methane and without significant accumulation of acetate or $\mathrm{H}_{2}$. Contrary to previous explanations of the effects of $\mathrm{NH}_{3}-\mathrm{N}$ concentration higher than $1000 \mathrm{mg} \mathrm{L}^{-1}$, acetoclastic methanogens played a major role in methane production. Our results point to syntrophies that involved acetoclastic methanogens, hydrogenotrophic methanogens, homoacetogens, and other syntrophic acid-fermenting Bacteria developed during the startup of a methanogenic bioreactor able to function well with $\mathrm{NH}_{3}-\mathrm{N}$ greater than $\sim 2000 \mathrm{mg} \mathrm{NH}_{3}-\mathrm{N} \mathrm{L}^{-1}$.

\section{Materials and Methods}

2.1. Anaerobic Bioreactor Setup and Operation. The bioreactor consisted of a 1-L glass vessel continuously stirred at $170 \mathrm{rpm}$ and operated at $37^{\circ} \mathrm{C}$ and at a $\mathrm{pH}$ of 6.9-7.6. The reactor was inoculated with 1:2 volume ratio of anaerobic digested sludge to swine waste to ensure that the concentration of $\mathrm{NH}_{3}-\mathrm{N}$ was below $1100 \mathrm{mg} \mathrm{N} \mathrm{L}^{-1}$. The anaerobic digester sludge was obtained from the Northwest Wastewater Reclamation Plant (Mesa, Arizona, USA) and the swine waste from Hormel Foods (Snowflake, Arizona, USA).

The bioreactor was operated in batch mode for 35 days, during which time methane production reached a plateau. Afterwards, the operation was switched to semicontinuous mode by daily removing and adding $33 \mathrm{~mL}$ of swine waste feed with a sterile syringe under vigorous $\mathrm{N}_{2}$ sparging. The hydraulic retention time (HRT), equal to the solids retention time (SRT), was 35 days (denoted as "cycle" in the manuscript figures). The bioreactor was operated semicontinuously for 105 days.

2.2. Chemical Analyses. An array of chemical analyses was employed to characterize the input swine waste and to monitor the performance of the anaerobic reactor through liquid samples taken from the reactor's homogenized contents. Total and soluble chemical oxygen demand (TCOD and SCOD), soluble total nitrogen (TN), and $\mathrm{NH}_{3}-\mathrm{N}$ were assayed with $\mathrm{HACH}^{\circledR}$ kits using spectrophotometer absorbance at wavelengths of 620,410 , and $655 \mathrm{~nm}$, respectively. Soluble concentrations were measured after filtering the sample through a $0.45 \mu \mathrm{m}$ membrane filter.

Gas samples $(200 \mu \mathrm{L})$ were withdrawn from the bioreactor headspace using a $500 \mu \mathrm{L}$ gas-tight syringe (SGE, 
Switzerland) to quantify methane $\left(\mathrm{CH}_{4}\right)$ and hydrogen $\left(\mathrm{H}_{2}\right)$ concentrations using a gas chromatograph (GC 2010, Shimadzu) equipped with a thermal conductivity detector and a packed column (ShinCarbon ST 100/120 mesh, Restek Corporation). $\mathrm{N}_{2}$ was the carrier gas supplied at a constant pressure of $405 \mathrm{kPa}$ and a constant flow rate of $10 \mathrm{~mL} \mathrm{~min}^{-1}$, and the temperature conditions for injection, column, and detector were 110,140 , and $160^{\circ} \mathrm{C}$, respectively.

2.3. DNA Extraction. Four biomass samples were obtained from the inoculum and the effluent of the anaerobic bioreactor at the end of the batch operation and at the end of the first and second cycles of the semicontinuous operation, when the system was at steady state based on the COD removed as $\mathrm{CH}_{4}$. Effluent samples were pelleted using an Eppendorf microcentrifuge 5810R (Hauppauge, NY) at 13,200 rpm. DNA was extracted from $0.25 \mathrm{~g}$ (wet weight) of two pellets per sampling point using the MOBIO PowerSoil ${ }^{\circledR}$ DNA extraction kit (Carlsbad, CA). DNA from duplicate pellets was merged for sequencing.

2.4. High-Throughput Microbial Community Analysis. To determine the structure of the Bacterial community during startup of the semicontinuous reactor, we sequenced DNA using the Illumina MiSeq platform at University of Minnesota Genomics Center (http://www.health.umn.edu/research/resources-researchers/genomics-center). Bacterial primers used were V4F ( $5^{\prime}$-GTGCCAGCMGCCGCGGTAA-3') and V6R ( $5^{\prime}$-ACAGCCATGCANCACCT- $\left.3^{\prime}\right)$, which amplify the V4-V6 hypervariable regions of the 16S rRNA gene. The reads were paired-end, and each end of the DNA fragment consisted of $300 \mathrm{bp}(2 \times 300 \mathrm{bp})$. Before processing the reads using the QIIME 1.8.0 pipeline [29], we paired forward and reverse sequences using PANDASeq [30]. The average length of reads after overlap was $551 \mathrm{bp}$.

The Archaeal community was sequenced at MR DNA (http://www.mrdnalab.com/, Shallowater, TX, USA) on an Illumina MiSeq following the manufacturer's guidelines. 16S rRNA primers $349 \mathrm{~F}$ and $806 \mathrm{R}$, with barcode on the forward primer, were used to amplify the V3 and V4 hypervariable region of this highly conserved gene [31]. The reads were paired-end, and each end of the DNA fragment consisted of $300 \mathrm{bp}(2 \times 300 \mathrm{bp})$. The average length of reads after overlap was $449 \mathrm{bp}$. Bacterial and Archaeal raw sequences were submitted to NCBI Sequence Read Archive and are available under the following accession numbers: SAMN04481086SAMN04481094.

Sequences with at least one of the following characteristics were omitted for the downstream analysis: being shorter than 200 bps, with quality score of 25 or below, with any primer or barcode mismatches, and with more than 6 homopolymers. From the sequences that passed the quality filtering, OTUs were picked based on $97 \%$ sequence similarity using the UCLUST algorithm [32]. The most abundant sequence of each cluster was picked as the representative sequence. Sequences were aligned using the PyNAST method [33] and filtered to remove gaps and Chimeras (using ChimeraSlayer [34]). The UCLUST algorithm [32] was used to assign taxonomy to the most abundant sequence of each
OTU by comparing the most abundant sequence of each OUT to the Greengenes database [35]. OTU tables (1 each for Bacterial and Archaeal sequences) were generated from the representative sequences excluding Chimeras. OTUs with single sequences (singletons) were removed from the OTU tables. To avoid biases that occur when sampling various species in a community, OTU tables were subsampled (rarefied) using the pseudorandom number generator (PRNG) NumPy, an implementation of the Mersenne PRNG [36]. Final OTUs numbers were 3275 for Bacteria and 776 for Archaea. The numbers of high-quality reads per sample in the Bacteria and Archaea analysis were 25,000 and 90,000 sequences, respectively, on average.

2.5. Sample Diversity. We calculated sample species diversity (alpha diversity) by estimating PD- (Phylogenetic Distance-) whole-tree and observed-species metrics using the QIIME 1.8.0 pipeline [29]. For this, we performed multiple subsamplings (rarefactions) of the OTU table (Bacteria and Archaea separately) at a depth of 100 sequences in 10 replicates, and we analyzed rarefaction measures in which the sequence numbers per sample were equal (18,000 sequences per sample for Bacteria and 32,000 for Archaea).

2.6. Quantitative Real-Time PCR ( $q P C R)$. We performed qPCR in $20 \mu \mathrm{L}$ reactions, each containing $6 \mu \mathrm{L}$ PCR grade water, $0.04 \mu \mathrm{L}$ TAQMAN probe $(200 \mathrm{nM}), 1 \mu \mathrm{L}$ each of forward and reverse primers $(500 \mathrm{nM}), 10 \mu \mathrm{L}$ TAQ PCR SuperMix (1X) or SYBR green mix (1X), and $2 \mu \mathrm{L}$ template normalized DNA to $10 \mathrm{ng} / \mu \mathrm{L}(130 \mathrm{nM})$. Using TAQMAN assays, we used the qPCR primers and conditions described previously $[37,38]$ for the amplification of the 16S rRNA gene of Archaea, the methanogenic orders (Methanomicrobiales, Methanobacteriales, and Methanococcales), and the families Methanosaetaceae and Methanosarcinaceae. We also used qPCR to target the 16S rRNA gene of Bacteria [39] and the highly conserved formyl tetrahydrofolate synthase (FTHFS) gene in homoacetogens by performing SYBR green assays, using methods described previously [38].

2.7. Statistical Analysis. Using the Statistical Package for the Social Sciences (SPSS) software, we performed Pearson's parametric correlation among variables of interest: methane production, total $\mathrm{N}$ and $\mathrm{NH}_{3}-\mathrm{N}$ concentrations, and key fermenters, syntrophs, and hydrogenotrophic and acetoclastic methanogens identified through sequencing analysis. These variables were picked based on the hypothesis that $\mathrm{NH}_{3}$ $\mathrm{N}$ would have an effect on microbial community structure, specifically on methanogens, and correction for multiple comparisons was not performed. $P<0.05$ was accepted as significant.

\section{Results and Discussion}

3.1. COD Was Converted into Methane during Bioreactor Operation despite $\mathrm{NH}_{3}-\mathrm{N}>2000 \mathrm{mg} / \mathrm{L}$. We monitored total and soluble COD, $\mathrm{NH}_{3}-\mathrm{N}$ and total $\mathrm{N}$, and methane and biogas production rates at regular intervals during the startup phase of the methanogenic reactor treating swine waste. 


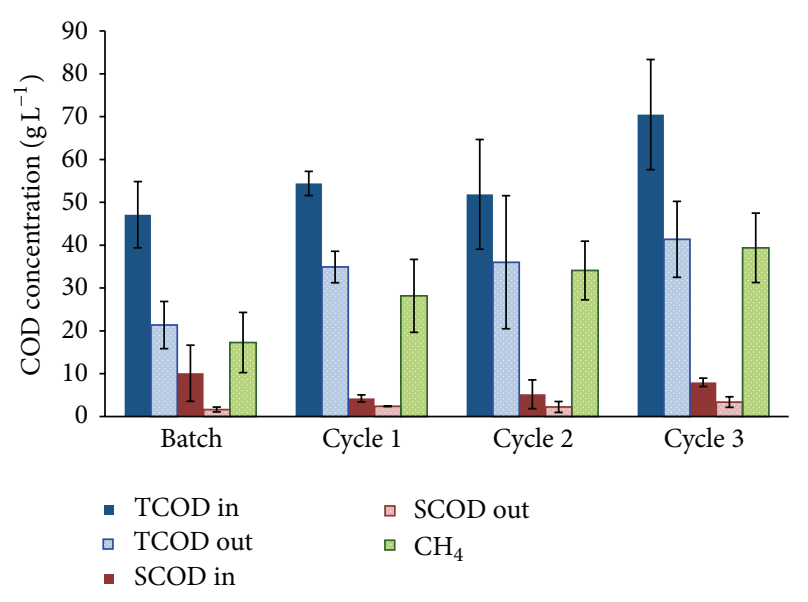

Figure 1: Total COD (TCOD) and soluble COD (SCOD) in the influent and effluent of the reactor and the COD content of the total methane $\left(\mathrm{CH}_{4}\right)$ produced during each operating phase (batch and 3 cycles of semicontinuous operation). The data are averages with standard deviations of three or more measurements.

The results are summarized in Figures 1 and 2 and S1, in Supplementary Material available online at http://dx.doi.org/ 10.1155/2016/4089684; Table S1 documents good COD massbalance closure at four sampling times. Based on COD removed as $\mathrm{CH}_{4}$, the performance of the reactor approached a pseudo-steady state in cycle 1 of semicontinuous operation, with approximately $52 \%$ conversion. $\mathrm{CH}_{4}$ was $70 \% \pm 16 \%$ of the biogas, and $\mathrm{H}_{2}$ concentrations were below detectable levels $(<0.5 \% \mathrm{v} / \mathrm{v})$ throughout the experiment. During semicontinuous operation, effluent soluble COD (which is composed of relatively small, biodegradable molecules [39]) represented only $4.5 \% \pm 0.3 \%$ of the influent TCOD or $\leq 2.6 \pm$ $0.6 \mathrm{~g} \mathrm{COD} \mathrm{L}^{-1}$. This low SCOD concentration implies that short-chain fatty acids (including propionate, butyrate, and acetate), which mainly comprise the SCOD, did not accumulate because they were consumed by microbial metabolism leading to methane production and biomass synthesis.

Figure 2(a) shows $\mathrm{NH}_{3}-\mathrm{N}$ increased from $890 \pm$ $295 \mathrm{mg} \mathrm{NH} \mathrm{NL}_{3}-\mathrm{NL}^{-1}$ during batch operation to $2040 \pm$ $30 \mathrm{mg} \mathrm{NH}_{3}-\mathrm{NL}^{-1}$ during semicontinuous operation. The concentration of soluble total $\mathrm{N}$ (the sum of $\mathrm{NH}_{3}-\mathrm{N}$ and organic $\mathrm{N}$ ) paralleled that of $\mathrm{NH}_{3}-\mathrm{N}$ and was about $50 \%$ higher than total $\mathrm{NH}_{3}-\mathrm{N}$. This increasing release of organic $\mathrm{N}$ and $\mathrm{NH}_{3}-\mathrm{N}$ indicates that hydrolysis and fermentation of the protein fraction of the animal wastes increased after startup and stabilized in cycle 2. Figure 2(b) shows that methanogenesis continued to increase into cycle 3 , even though hydrolysis and fermentation of protein stabilized. Higher methane generation was possible in cycle 3 because the input TCOD increased with the batch of swine waste used in that cycle; the input $\mathrm{N}$ did not increase in parallel with input TCOD because the feed collected swine manure was not uniform throughout the experimental period.

3.2. The Diversity of Archaea and Bacteria Decreased with Increasing $\mathrm{NH}_{3}-\mathrm{N}$ Concentration. Table 2 summarizes the coefficients of the two metrics used to analyze diversity within the samples. PD-whole-tree, which is based on the phylogenetic tree, uses the branch lengths as a measure of diversity; the observed-species metric counts all unique OTUs in the sample [40]. Both metrics had similar decreasing trends for Archaea and Bacteria over time as the $\mathrm{NH}_{3}-\mathrm{N}$ concentration rose from $684 \mathrm{mg} \mathrm{NH}_{3}-\mathrm{N} \mathrm{L}^{-1}$ at the startup of the reactor to $890 \pm 295 \mathrm{mg} \mathrm{NH}_{3}-\mathrm{N} \mathrm{L}^{-1}$ in batch operation and to $2040 \pm 30 \mathrm{mg} \mathrm{NH}_{3}-\mathrm{N} \mathrm{L}^{-1}$ for continuous operation. These significant decreases suggest selective enrichment of microorganisms tolerant to $\mathrm{NH}_{3}-\mathrm{N}$.

\subsection{Hydrogenotrophic and Acetoclastic Methanogens Were} Abundant at $\sim 2000 \mathrm{mgNH}_{3}-\mathrm{NL}^{-1}$. We analyzed the Archaeal microbial community during reactor startup using high-throughput sequencing in order to evaluate how well acetoclastic methanogens (grouped under Methanosarcinales) or hydrogenotrophic methanogens (grouped under Methanobacteriales, Methanomicrobiales, Methanococcales, and the $\mathrm{E} 2$ order) were tolerant to $\mathrm{NH}_{3}-\mathrm{N}$ concentrations of $\sim 2000 \mathrm{mg} \mathrm{L}^{-1}$. Figure 3 compares the Archaeal communities in the inoculum with the communities after batch and semicontinuous operation. Phylotypes within the phylum Euryarchaeota (i.e., Methanomicrobiales, Methanobacteriales, E2 group, and Methanosarcinales) and those of the order pGrfc26 (within Crenarchaeota) [41] increased during the semicontinuous operation at $2040 \pm 30 \mathrm{mg} \mathrm{NH}_{3}-\mathrm{N} \mathrm{L}^{-1}$, while the unidentified phylotypes decreased from 38.6 to $1.5 \%$. These results confirm enrichment during the gradual acclimation to high and increasing total-ammonium concentrations.

The relative abundance of hydrogenotrophic and acetoclastic methanogens increased over time. This agrees with increasing methane production, low effluent SCOD (including acetate in the measurement), and no detection of $\mathrm{H}_{2}$ during semicontinuous operation. Figure 3(b) shows 8 different genera of hydrogenotrophic methanogens identified, including Methanoculleus, Methanogenium, and Methanobrevibacter. Although the genus Methanosaeta was the sole acetoclastic methanogen identified by high-throughput sequencing, its relative abundance increased from $14 \%$ in batch operation to $25 \%$ during semicontinuous operation. This increase in relative abundance could be due to an increase in the absolute abundance of Methanosaeta or a decrease in the abundance of other phenotypes. qPCR results (summarized in Figure S2) are consistent with Figure 3 and suggest that Methanomicrobiales were the most abundant methanogens followed by Methanosaetaceae and lastly by Methanobacteriales.

It is likely that the first $35 \mathrm{~d}$ of batch operation, with $<1100 \mathrm{mg} \mathrm{N}-\mathrm{NH}_{3} \mathrm{~L}^{-1}$, provided an acclimation period for acetoclastic methanogens, and $\sim 2000 \mathrm{mg} \mathrm{NH}_{3}-\mathrm{N} \mathrm{L}^{-1}$ was not high enough to inhibit Methanosaeta, which were selected by the third cycle, relative to other Archaea. This corresponds to the finding by Schnürer and Nordberg that it took $3000 \mathrm{mg} \mathrm{NH}_{3}-\mathrm{NL}^{-1}$ to inhibit $\mathrm{NH}_{3}-\mathrm{N}$-acclimated Methanosaeta spp. [18] and that this family was not detected in anaerobic digesters treating chicken wastes with above $3400 \mathrm{mg} \mathrm{NH}_{3}-\mathrm{N} \mathrm{L}^{-1}$ [42]. However, a recent study reported that $\mathrm{NH}_{3}-\mathrm{N}$-acclimated Methanosaetaceae spp. were the 
TABLE 2: Diversity of each sample at different time points during the startup phase of the methanogenic reactor treating swine waste. At the highest $\mathrm{NH}_{3}-\mathrm{N}$ concentration, samples species diversity both for Archaea and for Bacteria was lowest.

\begin{tabular}{lccccc}
\hline \multirow{2}{*}{ Sample } & \multirow{2}{*}{$\mathrm{NH}_{3}$-N (mg/L) } & \multicolumn{2}{c}{ Bacteria } & \multicolumn{2}{c}{ Archaea } \\
& & $\mathrm{PD}$-whole-tree & Observed-species & PD-whole-tree & Observed-species \\
\hline Inoculum & $\mathrm{N} / \mathrm{A}$ & $67 \pm 0.3$ & $1512 \pm 10$ & $24 \pm 0.2$ & $375 \pm 6$ \\
Batch & $<1100$ & $62 \pm 0.3$ & $1419 \pm 7$ & $25 \pm 0.4$ & $474 \pm 10$ \\
${ }^{*}$ Semicontinuous & $\sim 2000$ & $52 \pm 0.4$ & $1173 \pm 12$ & $21 \pm 0.1$ & $361 \pm 2$ \\
\hline
\end{tabular}

${ }^{*}$ The indices corresponding to semicontinuous operation are averages of the indices for samples taken on days 70 and 105.

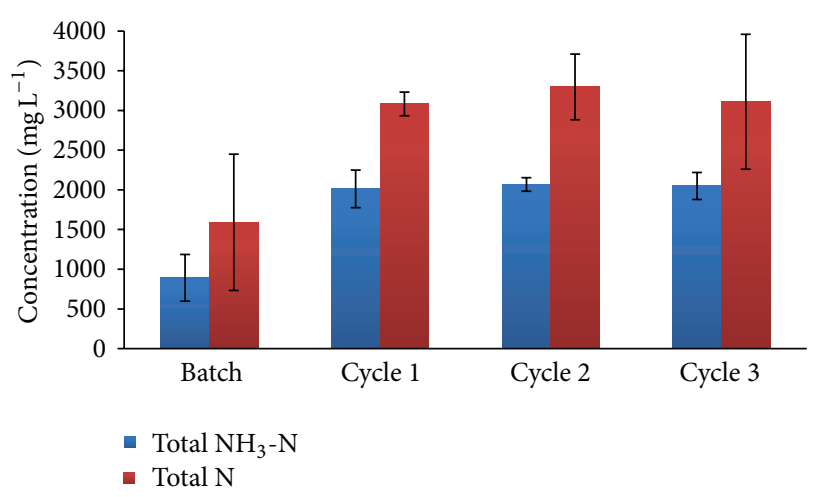

(a)

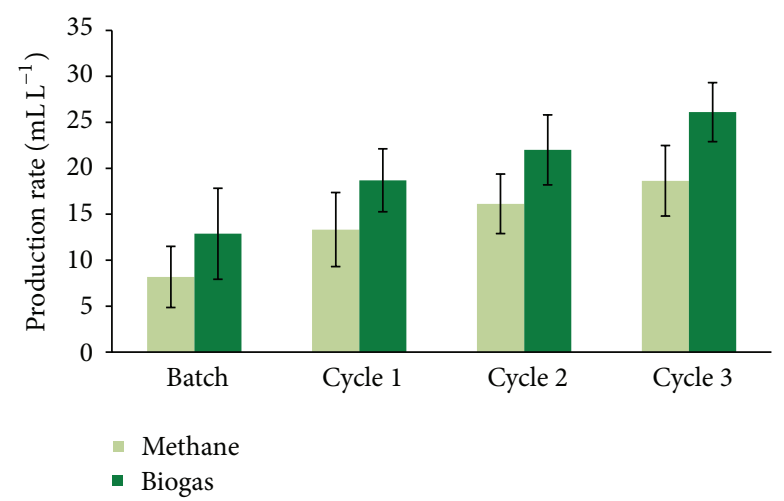

(b)

FIGURE 2: (a) Total nitrogen and $\mathrm{NH}_{3}-\mathrm{N}$ concentrations and (b) methane and total biogas production rates during batch and semicontinuous operation. The data are averages with standard deviations of three or more measurements during each operating phase.

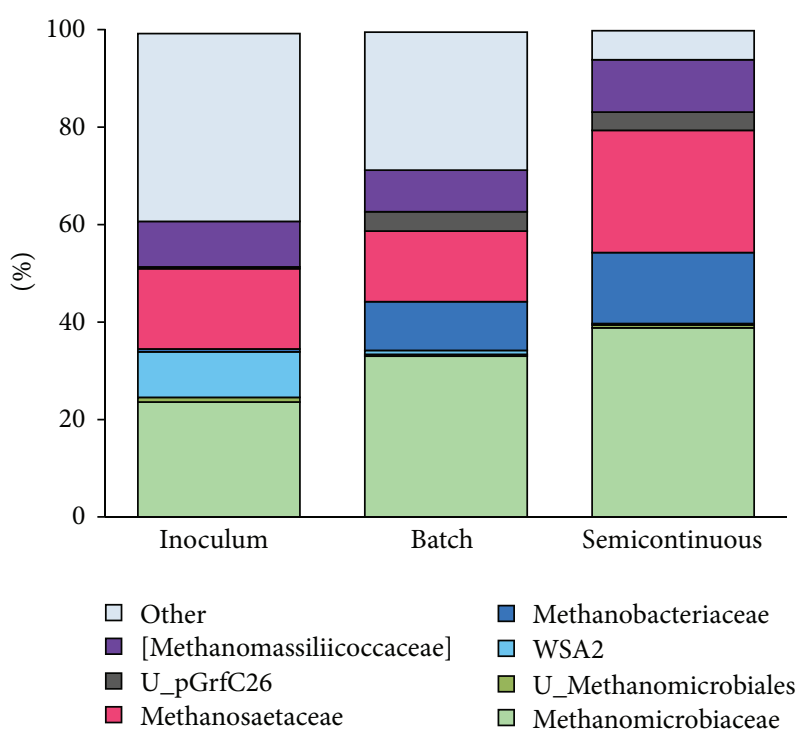

(a)

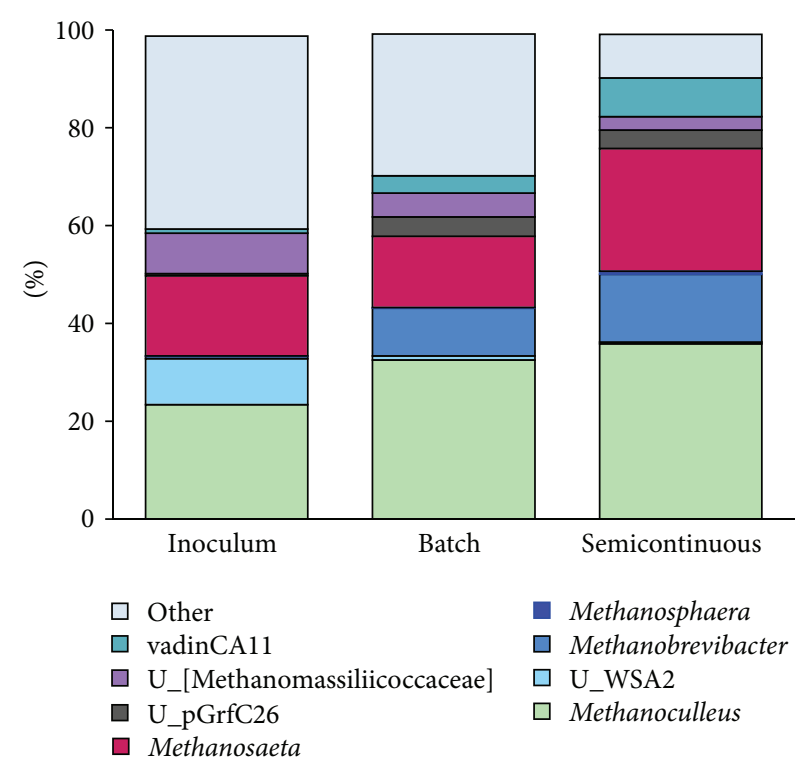

(b)

Figure 3: Archaeal distributions. (a) Phylotypes at the family level. (b) Phylotypes at the genera level. Shades of green are for Methanomicrobiales (hydrogenotrophic methanogens), blue for Methanobacteriales (hydrogenotrophic methanogens), red for Methanosarcinales (acetoclastic methanogens), and black for pGrfC26. The total $\mathrm{NH}_{3}-\mathrm{N}$ concentration at the time of the batch sampling was $1140 \mathrm{mg} / \mathrm{L}$. Semicontinuous operation is an average of two samples at $\sim 2000 \mathrm{mg} \mathrm{NH}_{3}-\mathrm{N} / \mathrm{L}$. "U_" stands for unidentified microorganism within the taxonomic classification. 


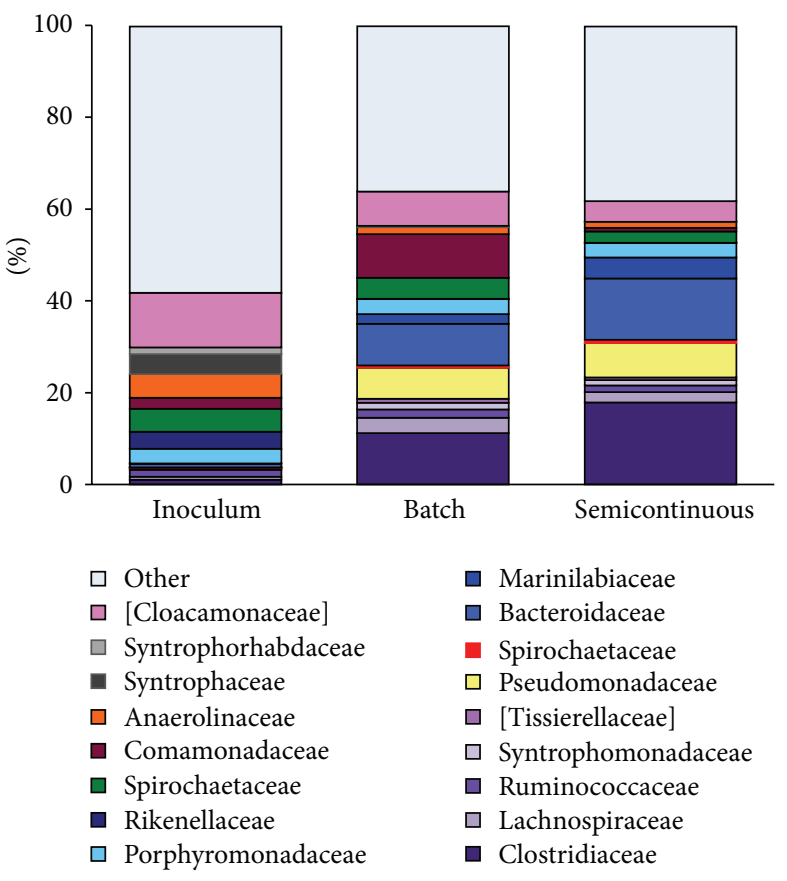

(a)

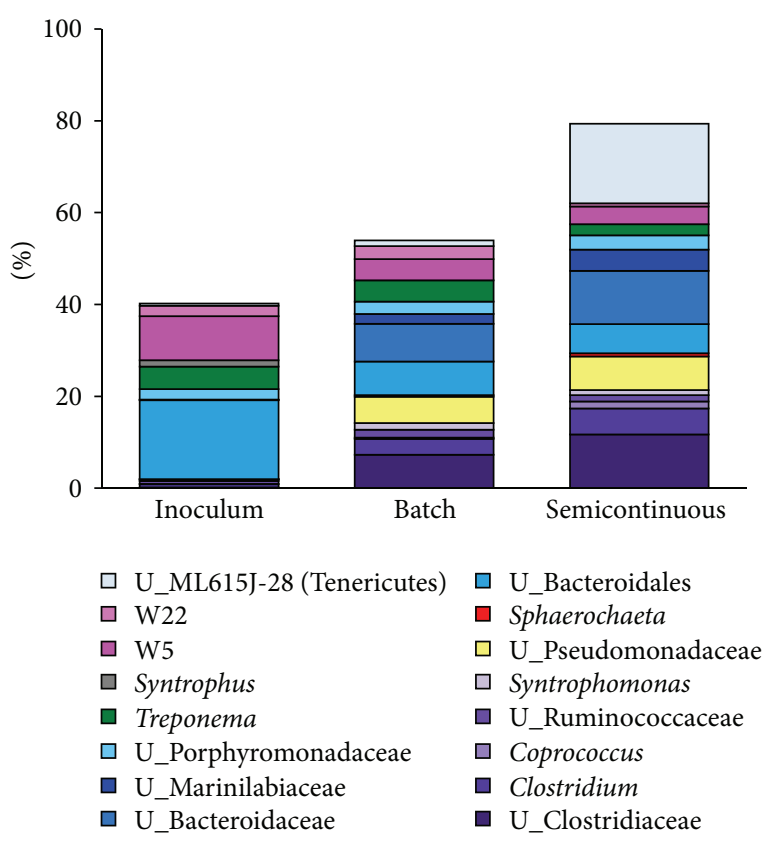

(b)

Figure 4: Bacterial distributions. (a) Phylotypes at the family level. (b) Most abundant phylotypes at the genera level. Similar colors (purple, yellow, black, blue, green, gray, and pink) indicate that the families are in the same order. The total $\mathrm{NH}_{3}-\mathrm{N}$ concentration at the time of the batch sampling was $1140 \mathrm{mg} / \mathrm{L}$. Semicontinuous operation is an average of two samples at $2000 \mathrm{mg} \mathrm{NH}_{3}-\mathrm{N} / \mathrm{L}$. "U_" stands for unidentified microorganism within the taxonomic classification.

most abundant acetoclastic methanogens identified in laboratory-scale anaerobic digesters operated at increasing $\mathrm{NH}_{3}-\mathrm{N}$ concentrations of up to $4000 \mathrm{mg} \mathrm{L}^{-1}[43]$.

\subsection{Acetogens Played a Key Role in Methane Production at} $\sim 2000 \mathrm{mgNH} \mathrm{NH}_{3}-\mathrm{NL}^{-1}$. The most abundant Bacterial phylotypes at the family and genus levels are summarized in Figure 4. At the genus level, phylotypes representative of producers of key short-chain fatty-acid (e.g., acetate, propionate, and butyrate) were enriched during exposure to high $\mathrm{NH}_{3}-\mathrm{N}$. These Bacteria are summarized in panel (b). The most abundant phylotypes were (i) Coprococcus, a butyrate- and acetate-producer within the Lachnospiraceae family [44], (ii) Sphaerochaeta (within the Spirochaetaceae family), an acetate-, formate-, and ethanol-producer [45], (iii) Treponema, acetogenic microorganisms within the Spirochaetaceae family, and (iv) unidentified phylotypes in the Bacteroidales and Clostridiales orders (represented in purple and blue, resp.), known to harbor microorganisms capable of fermenting carbohydrates and proteins to shortchain fatty-acids [46-48].

To elaborate on the acetogens, we used qPCR to quantify the highly conserved formyl tetrahydrofolate synthetase (FTHFS) gene of homoacetogens $[49,50]$ and reverseacetogens (sometimes called "syntrophic acetate oxidizers") $[6,21]$. Figure 5 shows a steady increase of the FTHFS gene; quantified FTHFS genes increased about two orders of magnitude from the beginning of the experiment to day 105 despite relative constant numbers of Bacterial 16S rRNA

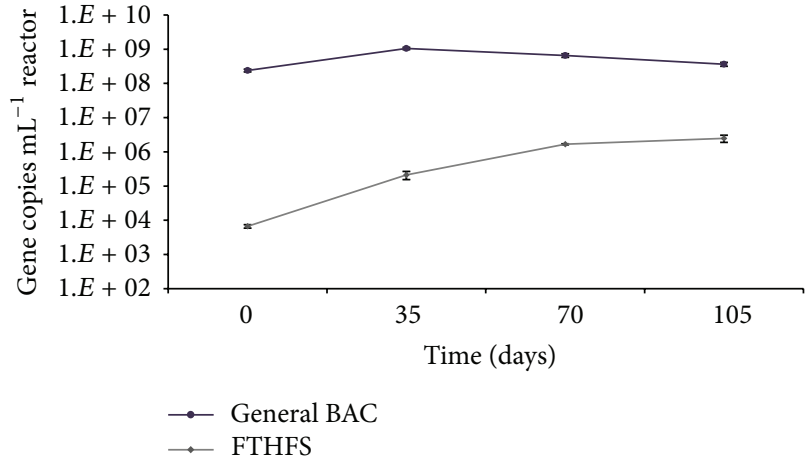

Figure 5: Gene copies for General Bacteria (BAC) and the FTHFS gene (marker of homoacetogens) over the duration of operation of the semicontinuous reactor.

genes. This indicates that there was not only an increase in homoacetogenic Bacteria but also a relative increase in their proportion of the Bacterial community, revealing an enrichment of homoacetogens with increasing $\mathrm{NH}_{3}-\mathrm{N}$ concentrations.

Low SCOD in the effluent, no detection of $\mathrm{H}_{2}$, and the high amount of acetoclastic and hydrogenotrophic methanogens mean that acetate and $\mathrm{H}_{2}$ were efficiently scavenged to produce $\mathrm{CH}_{4}$. The presence of homoacetogens means that the sink for acetate during semicontinuous operation could have been either one of the methanogenic pathways or both. Homoacetogens could either have been doing forward 
acetogenesis, in which case acetoclastic methanogens scavenge acetate, or have been doing reverse acetogenesis, in which hydrogenotrophic methanogens feed on $\mathrm{H}_{2}$ and $\mathrm{CO}_{2}$ generated from acetate.

Syntrophic acetate-utilizers were represented by phylotypes associated with the genus Clostridium within the Clostridiaceae family. Their relative abundance increased from $0.72 \%$ in the inoculum to 3.5 and $5.6 \%$ during batch and semicontinuous operation, respectively. Some strains (including C. ultunense [51] and strains similar to $C$. botulinum, C. sticklandii, and C. beijerinckii [52]) have been reported to perform reverse acetogenesis in methanogenic communities $[51,52]$. With high $\mathrm{NH}_{3}-\mathrm{N}$ concentration, these acetate-utilizers have been commonly found in syntrophy with hydrogenotrophic methanogens such as Methanoculleus $[13,53]$, the most abundant methanogen identified in our reactor. Thus, it is possible that several Clostridium spp. in our reactor contributed to methane production through reverse acetogenesis coupled with hydrogenotrophic methanogenesis.

\subsection{Syntrophic Fatty-Acid Fermenters Thrived at} $\sim 2000 \mathrm{mgNH}_{3}-\mathrm{NL}^{-1}$. In addition to syntrophic acetateutilizers among the Clostridia, propionate- and butyratefermenters that grow in syntrophy with hydrogenotrophic methanogens also were detected at relative abundances between 1.2 and $4.5 \%$ during semicontinuous operation. The detected phylotypes at the genus level were Syntrophomonas and W22 and W5. Syntrophomonas (within the Syntrophomonadaceae) ferment butyrate to acetate and $\mathrm{H}_{2}$ in syntrophic association with hydrogenotrophic methanogens and sulfate-reducers $[22,54]$. Cloacamonas, a representative genus of Cloacamonaceae, obtains its energy from the fermentation of amino acids and can ferment propionate to acetate, $\mathrm{H}_{2}$, and $\mathrm{CO}_{2}$ in syntrophy with $\mathrm{H}_{2}$ and acetate consumers [55, 56]. This syntroph has been named Candidatus Cloacamonas acidaminovorans, and although it has not been cultivated, its genome has been reconstructed by metagenomics [55]. Comparing the sequences (300 bp) associated with the W22 and W5 genera to available sequences (NCBI, BLAST) reveals that these genera share up to $96 \%$ similarity with Candidatus C. acidaminovorans. Therefore, it is possible that Cloacamonaceae and Syntrophomonadaceae contributed to methane production with $2040 \pm 30 \mathrm{mg} \mathrm{NH}_{3}-\mathrm{N} \mathrm{L}^{-1}$ by fermenting butyrate and propionate to $\mathrm{H}_{2}, \mathrm{CO}_{2}$, and acetate in syntrophy with hydrogenotrophic and acetoclastic methanogens.

3.6. Correlation Analysis Supports Syntrophies between Acetoclastic Methanogens with Acetogens and Hydrogenotrophic Methanogens with Syntrophic Fatty-Acid Fermenters. In order to understand the effect of $\mathrm{NH}_{3}-\mathrm{N}$ and total $\mathrm{N}$ concentrations on methane production and the microbial community structure, we calculated Pearson's R coefficient among methane production rates, $\mathrm{NH}_{3}-\mathrm{N}$ and total $\mathrm{N}$ concentrations, and fermenters, syntrophs, and hydrogenotrophic and acetoclastic methanogens identified at four time points during operation of the anaerobic reactor treating swine waste. The results of the parametric correlation analysis are summarized in Figure 6. Hydrogenotrophic methanogens (Methanoculleus, Methanogenium, Methanobrevibacter, and an unidentified genus within Methanomicrobiales) and acetoclastic Methanosaeta were positively correlated with total $\mathrm{N}$ and $\mathrm{NH}_{3}-\mathrm{N}$ concentrations (in some cases, correlations were significant at the 0.05 level). These positive correlations suggest that hydrogenotrophic and acetoclastic methanogens thrived with increasing $\mathrm{NH}_{3}-\mathrm{N}$ concentration up to $2040 \pm 30 \mathrm{mg} \mathrm{NH}_{3}-\mathrm{NL}^{-1}$ when the $\mathrm{pH}$ was $6.9-7.6$ and the HRT was $35 \mathrm{~d}$. Moreover, acetogens/fermenters Coprococcus, Sphaerochaeta, and an unidentified genus within Porphyromonadaceae were positively correlated with $\mathrm{NH}_{3}-\mathrm{N}$ and almost all methanogens and, consequently, correlation with methane production was positive. These positive correlations underscore the important role of acetogens for methane production at high $\mathrm{NH}_{3}-\mathrm{N}$.

Unidentified Clostridiaceae, which comprises several short-chain fatty-acid producers, and Clostridium had positive correlations with acetoclastic Methanosaeta, and this supports acetate generation by acetogens and homoacetogens. However, unidentified Clostridiaceae also showed a positive correlation with unidentified hydrogenotrophic Methanomicrobiales and with hydrogenotrophs Methanogenium and Methanoculleus. This supports that homoacetogens among the Clostridiaceae were possibly carrying out reverse acetogenesis. Thus, parametric analysis supports an important role for homoacetogens, but it cannot determine whether they were performing forward or reverse acetogenesis.

\section{Conclusions}

Successful operation of an anaerobic reactor treating swine manure proved that Bacterial and Archaeal communities could acclimate to a steady increase in total $\mathrm{NH}_{3}-\mathrm{N}$ concentration up to $2040 \pm 30 \mathrm{mg} \mathrm{NH}_{3}-\mathrm{N} \mathrm{L}^{-1}$. Both communities became less diverse over time. $\mathrm{NH}_{3}-\mathrm{N}$ tolerant phylotypes that were enriched include (1) acetoclastic methanogens (Methanosaeta); (2) Clostridia known to do forward and reverse acetogenesis (Clostridium and Clostridiaceae spp.); (3) fatty-acid producers (Coprococcus and Sphaerochaeta); (4) hydrogenotrophic methanogens (Methanoculleus, Methanobrevibacter, and Methanogenium); and (5) syntrophic fattyacid fermenters (Syntrophomonas, Clostridium, Clostridiaceae spp., and possibly Cloacamonaceae species). Our results suggest that the gradual increase in the $\mathrm{NH}_{3}-\mathrm{N}$ concentration led to a microbial community acclimated to the high total $\mathrm{NH}_{3}$ concentrations associated with anaerobic digestion of animal wastes. As summarized in Figure 7, acetoclastic and hydrogenotrophic methanogens could coexist in the presence of $\mathrm{NH}_{3}-\mathrm{N}$ concentrations $\sim 2000 \mathrm{mg} \mathrm{L}^{-1}$ by establishing syntrophic relationships with propionate and butyrate-fermenters, as well as homoacetogens able to carry out forward and reverse acetogenesis.

\section{Disclosure}

Any opinions, findings, and conclusions or recommendations expressed in this material are those of the authors and do not necessarily reflect those of the NSF. 


\begin{tabular}{|c|c|c|c|c|c|c|c|c|c|c|c|c|}
\hline \\
\hline TAN & 1.00 & $\begin{array}{l}\text { lotal_N } \\
1.00\end{array}$ & Methane & & & & & & & & & \\
\hline $\begin{array}{r}\text { Total N } \\
\text { Methane }\end{array}$ & 0.76 & & & Сoproco & & & & & & & & \\
\hline $\begin{array}{r}\text { Methane } \\
\text { Coprococcus }\end{array}$ & 0.90 & 0.97 & 1.00 & 100 & U_Porp & yromona & aceae & & & & & \\
\hline $\begin{array}{r}\text { Coprococcus } \\
\text { U_Porphyromonadaceae }\end{array}$ & $\begin{array}{l}0.99 \\
0.59\end{array}$ & 0.67 & 0.83 & 0.47 & 1.00 & Sphaero & aceae & & & & & \\
\hline & 0.59 & & & & & & & & & & & \\
\hline $\begin{array}{r}\text { Sphaerochaeta } \\
\text { Syntrophomonas }\end{array}$ & 0.62 & 0.98 & 0.90 & 0.51 & & 1.00 & Syntropl & monas & & & & \\
\hline $\begin{array}{l}\text { Syntrophomonas } \\
\text { W5_Cloacamonaceae }\end{array}$ & -0.69 & -0.06 & -0.30 & -0.78 & 0.18 & 0.14 & 1.00 & W5_Clc & camona & & & \\
\hline & -0.67 & -0.99 & -0.93 & -0.56 & -1.00 & $-1.00^{*}$ & -0.08 & 1.00 & W22_Cl & acamona & eae & \\
\hline $\begin{array}{r}\text { W22_Cloacamonaceae } \\
\text { Clostridium }\end{array}$ & -1.00 & -0.81 & -0.93 & -0.98 & -0.64 & -0.67 & 0.64 & 0.72 & 1.00 & Clostridt & & \\
\hline $\begin{array}{l}\text { Clostridium } \\
\text { U Clostridiaceae }\end{array}$ & 0.94 & 0.48 & 0.68 & 0.97 & 0.26 & 0.30 & -0.90 & -0.36 & -0.91 & 1.00 & U_Clos & idiaceae \\
\hline U_Clostridiaceae & 0.73 & $1.00^{*}$ & 0.96 & 0.64 & 0.98 & 0.99 & -0.01 & -1.00 & -0.78 & 0.45 & 1.00 & U_Bacteroidaceae \\
\hline U_Bacteroidaceae & 0.27 & -0.42 & -0.19 & 0.39 & -0.63 & -0.60 & -0 & 0.54 & -0.20 & 0.59 & -0.46 & 1.00 \\
\hline U_PGrtC26 & -0.36 & -0.88 & -0.74 & -0.24 & -0.97 & -0.96 & -0.42 & 0.94 & 0.43 & -0.01 & -0.90 & 0.80 \\
\hline Methanobrevibacter & 0.53 & -0.15 & 0.09 & 0.63 & -0.38 & -0.34 & -0.98 & 0.28 & -0.46 & 0.79 & -0.19 & 0.96 \\
\hline U_Methanomicrobiales & 0.78 & $1.00^{*}$ & 0.98 & 0.70 & 0.96 & 0.97 & -0.09 & -0.99 & -0.83 & 0.52 & $1.00^{* *}$ & -0.39 \\
\hline Methanoculleus & $1.00^{*}$ & 0.77 & 0.90 & 0.99 & 0.60 & 0.63 & -0.68 & -0.68 & $-1.00^{*}$ & 0.93 & 0.74 & 0.25 \\
\hline Methanogenium & 0.72 & $1.00^{*}$ & 0.96 & 0.63 & 0.98 & 0.99 & 0.00 & -1.00 & -0.77 & 0.43 & 1.00 & -0.48 \\
\hline Methanosaeta & 0.94 & 0.94 & 1.00 & 0.88 & 0.83 & 0.85 & -0.39 & -0.89 & -0.96 & 0.75 & 0.93 & -0.09 \\
\hline
\end{tabular}

Pearson's R coefficient

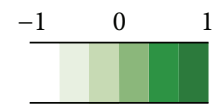

FIgURE 6: Parametric correlation (Pearson's R coefficient) of methane production, total $\mathrm{NH}_{3}-\mathrm{N}$ (TAN) concentration, and key Bacteria and Archaea identified during operation of the anaerobic reactor treating swine waste. Phylotypes in purple, orange, blue, and red represent fermenters, syntrophs, and hydrogenotrophic and acetoclastic methanogens, respectively. Phylotypes that are most similar to fermenters and syntrophs are indicated in a combination of purple and orange colors. Note. ${ }^{*}$ Correlation is significant at the 0.05 level (2-tailed). ${ }^{* *}$ Correlation is significant at the 0.01 level (2-tailed). The statistical analysis was not corrected for multiple comparisons.

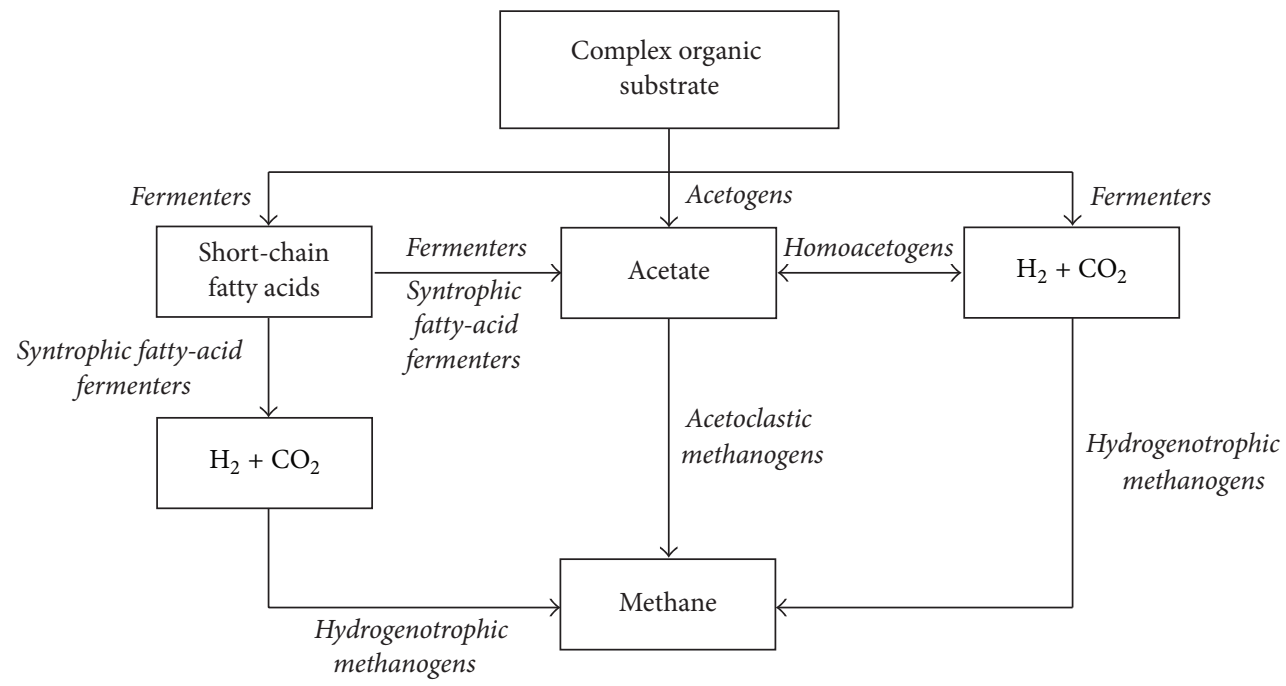

Figure 7: Proposed key anaerobic food-web reactions occurring at ammonia-N concentrations of $\sim 2000 \mathrm{NH}_{3}-\mathrm{N} \mathrm{mg} \mathrm{L}^{-1}$.

\section{Competing Interests}

The authors declare that there is no conflict of interests regarding the publication of this paper.

\section{Authors' Contributions}

Sofia Esquivel-Elizondo and Prathap Parameswaran contributed equally to this work.

\section{Acknowledgments}

This work was supported in part by the National Science Foundation CAREER Program [Grant no. 1053939].

\section{References}

[1] Annual Report of the Manure and Byproduct Utilization National Program, 2006. 
[2] Water Environment Federation, A Guide to Understanding Biosolids Issues, 2002.

[3] E. Metcalf, Wastewater Engineering: Treatment and Reuse, McGraw-Hill, Boston, Mass, USA, 2003.

[4] M. Russelle, K. Blanchet, G. Randall, and L. Everett, Nitrogen Availability from Liquid Swine and Dairy Manure: Results of On-Farm Trials in Minnesota, Regents of the University of Minnesota, Minneapolis, Minn, USA, 2013, http://www.extension.umn.edu/agriculture/nutrient-management/nitrogen/nitrogen-availability-from-liquid-swine-and-dairy-manure/\#sources.

[5] J. P. Chastain, J. J. Camberato, J. E. Albrecht, and I. Jesse Adams, "Swine manure production and nutrient content," in CAMM Poult, pp. 3-18, 2003.

[6] M. Westerholm, B. Müller, V. Arthurson, and A. Schnürer, "Changes in the acetogenic population in a mesophilic anaerobic digester in response to increasing ammonia concentration," Microbes and Environments, vol. 26, no. 4, pp. 347-353, 2011.

[7] A. F. M. Van Velsen, "Adaptation of methanogenic sludge to high ammonia-nitrogen concentrations," Water Research, vol. 13, no. 10, pp. 995-999, 1979.

[8] A. G. Delgado, D. Fajardo-Williams, K. L. Kegerreis, P. Parameswaran, and R. Krajmalnik-Brown, "Impact of ammonium on syntrophic organohalide-respiring and fermenting microbial communities," mSphere, vol. 1, no. 2, Article ID e00053-16, 2016.

[9] H. M. Poggi Varaldo, J. Tingley, and J. A. Oleszkiewicz, "Inhibition of growth and acetate uptake by ammonia in batch anaerobic-digestion," Journal of Chemical Technology and Biotechnology, vol. 52, pp. 135-143, 1991.

[10] S. R. Hajarnis and D. R. Ranade, "Revival of ammonia inhibited cultures of Methanobacterium bryantii and Methanosarcina barkeri," Journal of Fermentation and Bioengineering, vol. 76, no. 1, pp. 70-72, 1993.

[11] P. L. McCarty, "Anaerobic waste treatment fundamentals. Part one: chemistry and microbiology," Public Works, vol. 95, pp. 107-112, 1964.

[12] A. W. Walker, S. H. Duncan, E. C. M. Leitch, M. W. Child, and H. J. Flint, "pH and peptide supply can radically alter bacterial populations and short-chain fatty acid ratios within microbial communities from the human colon," Applied and Environmental Microbiology, vol. 71, no. 7, pp. 3692-3700, 2005.

[13] T. Shigematsu, Y. Tang, T. Kobayashi, H. Kawaguchi, S. Morimura, and K. Kida, "Effect of dilution rate on metabolic pathway shift between aceticlastic and nonaceticlastic methanogenesis in chemostat cultivation," Applied and Environmental Microbiology, vol. 70, no. 7, pp. 4048-4052, 2004.

[14] D. Karakashev, D. J. Batstone, E. Trably, and I. Angelidaki, "Acetate oxidation is the dominant methanogenic pathway from acetate in the absence of Methanosaetaceae," Applied and Environmental Microbiology, vol. 72, no. 7, pp. 5138-5141, 2006.

[15] L. T. Angenent, S. Sung, and L. Raskin, "Methanogenic population dynamics during startup of a full-scale anaerobic sequencing batch reactor treating swine waste," Water Research, vol. 36, no. 18 , pp. 4648-4654, 2002.

[16] I. W. Koster and G. Lettinga, "The influence of ammoniumnitrogen on the specific activity of pelletized methanogenic sludge," Agricultural Wastes, vol. 9, no. 3, pp. 205-216, 1984.

[17] K. Sasaki, M. Morita, S.-I. Hirano, N. Ohmura, and Y. Igarashi, "Decreasing ammonia inhibition in thermophilic methanogenic bioreactors using carbon fiber textiles," Applied Microbiology and Biotechnology, vol. 90, no. 4, pp. 1555-1561, 2011.
[18] A. Schnürer and Å. Nordberg, "Ammonia, a selective agent for methane production by syntrophic acetate oxidation at mesophilic temperature," Water Science and Technology, vol. 57, no. 5, pp. 735-740, 2008.

[19] M. Westerholm, L. Levén, and A. Schnürer, "Bioaugmentation of syntrophic acetate-oxidizing culture in biogas reactors exposed to increasing levels of ammonia," Applied and Environmental Microbiology, vol. 78, no. 21, pp. 7619-7625, 2012.

[20] S. S. Hattori, "Syntrophic acetate-oxidizing microbes in methanogenic environments," Microbes and Environments, vol. 23, no. 2, pp. 118-127, 2008.

[21] M. Westerholm, J. Dolfing, A. Sherry, N. D. Gray, I. M. Head, and A. Schnürer, "Quantification of syntrophic acetateoxidizing microbial communities in biogas processes," Environmental Microbiology Reports, vol. 3, no. 4, pp. 500-505, 2011.

[22] N. Müller, P. Worm, B. Schink, A. J. M. Stams, and C. M. Plugge, "Syntrophic butyrate and propionate oxidation processes: from genomes to reaction mechanisms," Environmental Microbiology Reports, vol. 2, no. 4, pp. 489-499, 2010.

[23] J. C. M. Scholten and R. Conrad, "Energetics of syntrophic propionate oxidation in defined batch and chemostat cocultures," Applied and Environmental Microbiology, vol. 66, no. 7, pp. 2934-2942, 2000.

[24] P. Worm, J. J. Koehorst, M. Visser et al., "A genomic view on syntrophic versus non-syntrophic lifestyle in anaerobic fatty acid degrading communities," Biochimica et Biophysica Acta (BBA)_Bioenergetics, vol. 1837, no. 12, pp. 2004-2016, 2014.

[25] S. H. Zinder and M. Koch, "Non-aceticlastic methanogenesis from acetate: acetate oxidation by a thermophilic syntrophic coculture," Archives of Microbiology, vol. 138, no. 3, pp. 263-272, 1984.

[26] F. H. Liu, S. B. Wang, J. S. Zhang et al., "The structure of the bacterial and archaeal community in a biogas digester as revealed by denaturing gradient gel electrophoresis and $16 \mathrm{~S}$ rDNA sequencing analysis," Journal of Applied Microbiology, vol. 106, no. 3, pp. 952-966, 2009.

[27] L. Regueiro, P. Veiga, M. Figueroa, J. M. Lema, and M. Carballa, "Influence of transitional states on the microbial ecology of anaerobic digesters treating solid wastes," Applied Microbiology and Biotechnology, vol. 98, no. 5, pp. 2015-2027, 2014.

[28] A.-C. Liu, C.-Y. Chou, L.-L. Chen, and C.-H. Kuo, "Bacterial community dynamics in a swine wastewater anaerobic reactor revealed by $16 \mathrm{~S}$ rDNA sequence analysis," Journal of Biotechnology, vol. 194, pp. 124-131, 2015.

[29] J. G. Caporaso, J. Kuczynski, J. Stombaugh et al., "QIIME allows analysis of high-throughput community sequencing data," Nature Methods, vol. 7, no. 5, pp. 335-336, 2010.

[30] A. P. Masella, A. K. Bartram, J. M. Truszkowski, D. G. Brown, and J. D. Neufeld, "PANDAseq: paired-end assembler for illumina sequences," BMC Bioinformatics, vol. 13, no. 1, article 31, 2012.

[31] K. Takai and K. Horikoshi, "Rapid detection and quantification of members of the archaeal community by quantitative PCR using fluorogenic probes," Applied and Environmental Microbiology, vol. 66, no. 11, pp. 5066-5072, 2000.

[32] B. J. Haas, D. Gevers, A. M. Earl et al., "Chimeric 16S rRNA sequence formation and detection in Sanger and 454pyrosequenced PCR amplicons," Genome Research, vol. 21, no. 3, pp. 494-504, 2011.

[33] R. C. Edgar, "Search and clustering orders of magnitude faster than BLAST," Bioinformatics, vol. 26, no. 19, Article ID btq461, pp. 2460-2461, 2010. 
[34] J. G. Caporaso, K. Bittinger, F. D. Bushman, T. Z. Desantis, G. L. Andersen, and R. Knight, "PyNAST: a flexible tool for aligning sequences to a template alignment," Bioinformatics, vol. 26, no. 2, pp. 266-267, 2010.

[35] T. Z. DeSantis, P. Hugenholtz, N. Larsen et al., "Greengenes, a chimera-checked 16S rRNA gene database and workbench compatible with ARB," Applied and Environmental Microbiology, vol. 72, no. 7, pp. 5069-5072, 2006.

[36] M. Matsumoto and T. Nishimura, "Mersenne Twister: a 623dimensionally equidistributed uniform pseudo-random number generator," ACM Transactions on Modeling and Computer Simulation, vol. 8, no. 1, pp. 3-30, 1998.

[37] Y. Yu, C. Lee, J. Kim, and S. Hwang, "Group-specific primer and probe sets to detect methanogenic communities using quantitative real-time polymerase chain reaction," Biotechnology and Bioengineering, vol. 89, no. 6, pp. 670-679, 2005.

[38] P. Parameswaran, C. I. Torres, H.-S. Lee, B. E. Rittmann, and R. Krajmalnik-Brown, "Hydrogen consumption in microbial electrochemical systems (MXCs): the role of homo-acetogenic bacteria," Bioresource Technology, vol. 102, no. 1, pp. 263-271, 2011.

[39] K. M. Ritalahti, B. K. Amos, Y. Sung, Q. Wu, S. S. Koenigsberg, and F. E. Löffler, "Quantitative PCR targeting 16S rRNA and reductive dehalogenase genes simultaneously monitors multiple Dehalococcoides strains," Applied and Environmental Microbiology, vol. 72, no. 4, pp. 2765-2774, 2006.

[40] J. Kuczynski, J. Stombaugh, W. A. Walters, A. González, J. G. Caporaso, and R. Knight, "Using QIIME to analyze 16S rRNA gene sequences from microbial communities," in Current Protocols in Bioinformatics, Unit 10.7, pp. 10.7.1-10.7.20, 2011.

[41] K. L. Hershberger, S. M. Barns, A.-L. Reysenbach, S. C. Dawson, and N. R. Pace, "Wide diversity of Crenarchaeota," Nature, vol. 384, no. 6608, p. 420, 1996.

[42] D. E. Belostotskiy, E. E. Ziganshina, M. Siniagina, E. A. Boulygina, V. A. Miluykov, and A. M. Ziganshin, "Impact of the substrate loading regime and phosphoric acid supplementation on performance of biogas reactors and microbial community dynamics during anaerobic digestion of chicken wastes," Bioresource Technology, vol. 193, pp. 42-52, 2015.

[43] J. De Vrieze, S. Gildemyn, R. Vilchez-Vargas et al., "Inoculum selection is crucial to ensure operational stability in anaerobic digestion," Applied Microbiology and Biotechnology, vol. 99, no. 1, pp. 189-199, 2014.

[44] L. V. Holdeman and W. E. C. Moore, "New genus, Coprococcus, twelve new species, and emended descriptions of four previously described species of bacteria from human feces," International Journal of Systematic Bacteriology, vol. 24, no. 2, pp. 260-277, 1974.

[45] K. M. Ritalahti, S. D. Justicia-Leon, K. D. Cusick et al., "Sphaerochaeta globosa gen. nov., sp. nov. and Sphaerochaeta pleomorpha sp. nov., free-living, spherical spirochaetes," International Journal of Systematic and Evolutionary Microbiology, vol. 62, no. 1, pp. 210-216, 2011.

[46] S. Gronow, C. Munk, A. Lapidus et al., "Complete genome sequence of Paludibacter propionicigenes type strain $\left(\mathrm{WB}_{4}{ }^{\mathrm{T}}\right)$," Standards in Genomic Sciences, vol. 4, no. 1, pp. 36-44, 2011.

[47] S. Hahnke, I. Maus, D. Wibberg et al., "Complete genome sequence of the novel Porphyromonadaceae bacterium strain ING2-E5B isolated from a mesophilic lab-scale biogas reactor," Journal of Biotechnology, vol. 193, pp. 34-36, 2015.

[48] A. Biddle, L. Stewart, J. Blanchard, and S. Leschine, "Untangling the genetic basis of fibrolytic specialization by Lachnospiraceae and Ruminococcaceae in diverse gut communities," Diversity, vol. 5, no. 3, pp. 627-640, 2013.

[49] M. J. Lee and S. H. Zinder, "Carbon monoxide pathway enzyme activities in a thermophilic anaerobic bacterium grown acetogenically and in a syntrophic acetate-oxidizing coculture," Archives of Microbiology, vol. 150, no. 6, pp. 513-518, 1988.

[50] A. J. M. Stams, F. A. M. de Bok, C. M. Plugge, M. H. A. van Eekert, J. Dolfing, and G. Schraa, "Exocellular electron transfer in anaerobic microbial communities," Environmental Microbiology, vol. 8, no. 3, pp. 371-382, 2006.

[51] A. Schnürer, B. Schink, and B. H. Svensson, "Clostridium ultunense sp. nov., a mesophilic bacterium oxidizing acetate in syntrophic association with a hydrogenotrophic methanogenic bacterium," International Journal of Systematic Bacteriology, vol. 46, no. 4, pp. 1145-1152, 1996.

[52] S. Jiang, S. Park, Y. Yoon et al., "Methanogenesis facilitated by geobiochemical iron cycle in a novel syntrophic methanogenic microbial community," Environmental Science and Technology, vol. 47, no. 17, pp. 10078-10084, 2013.

[53] M. Westerholm, S. Roos, and A. Schnürer, "Tepidanaerobacter acetatoxydans sp. nov., an anaerobic, syntrophic acetateoxidizing bacterium isolated from two ammonium-enriched mesophilic methanogenic processes," Systematic and Applied Microbiology, vol. 34, no. 4, pp. 260-266, 2011.

[54] M. J. Mcinerney, M. P. Bryant, R. B. Hespell, and J. W. Costerton, "Syntrophomonas wolfei gen. nov. sp. nov., an anaerobic, syntrophic, fatty acid-oxidizing bacterium," Applied and Environmental Microbiology, vol. 41, no. 4, pp. 1029-1039, 1981.

[55] E. Pelletier, A. Kreimeyer, S. Bocs et al., "'Candidatus Cloacamonas acidaminovorans': genome sequence reconstruction provides a first glimpse of a new bacterial division," Journal of Bacteriology, vol. 190, no. 7, pp. 2572-2579, 2008.

[56] R. J. Siezen and M. Galardini, "Genomics of biological wastewater treatment," Microbial Biotechnology, vol. 1, no. 5, pp. 333-340, 2008. 

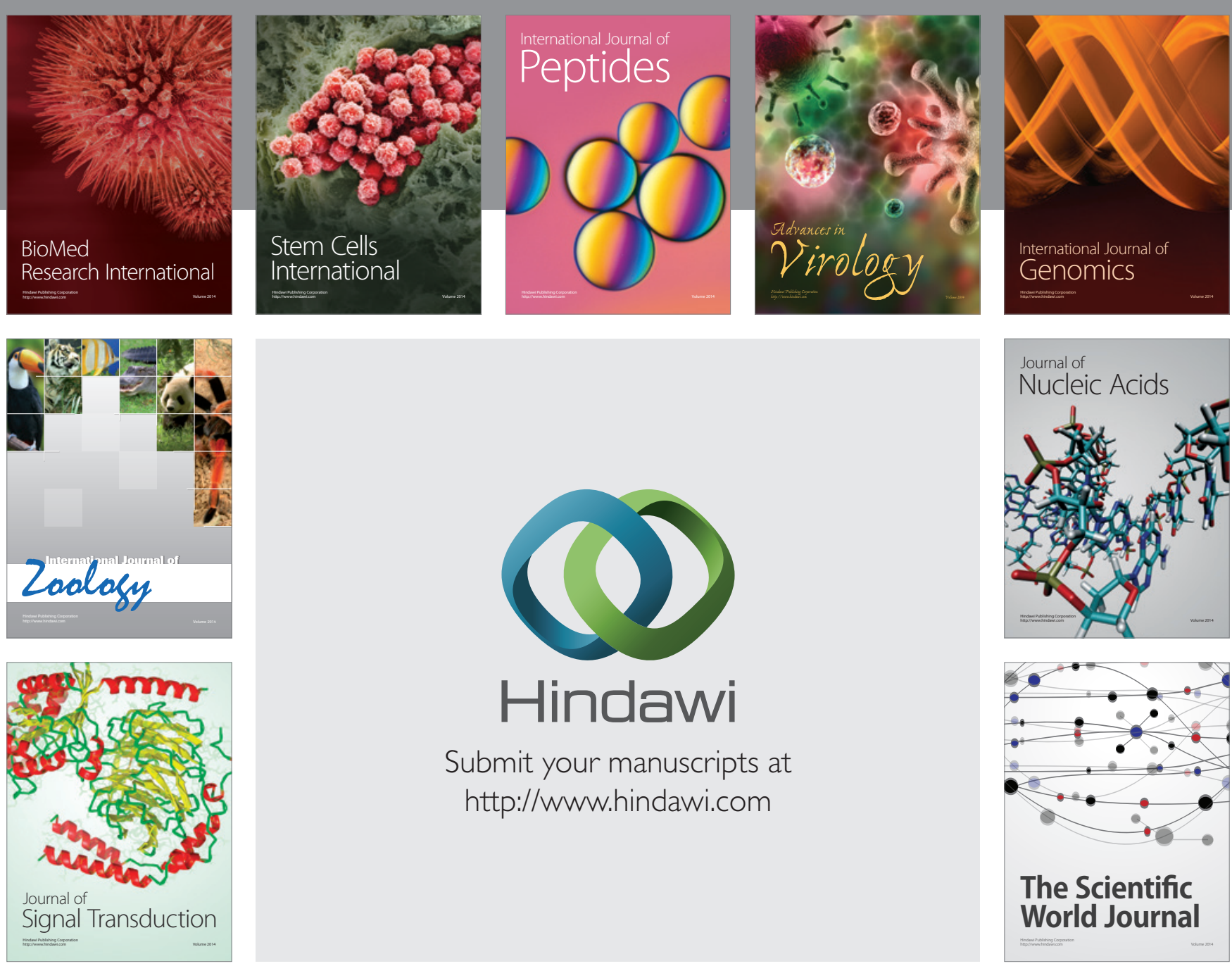

Submit your manuscripts at

http://www.hindawi.com
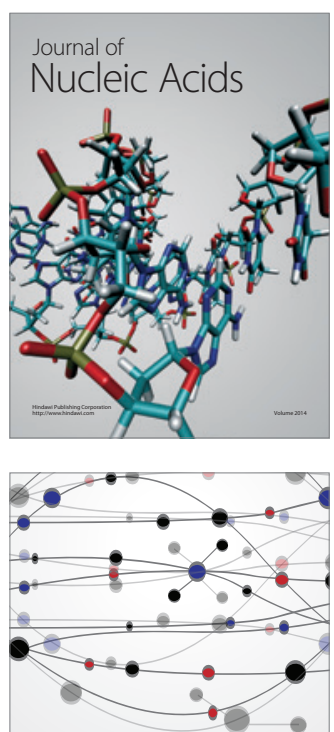

The Scientific World Journal
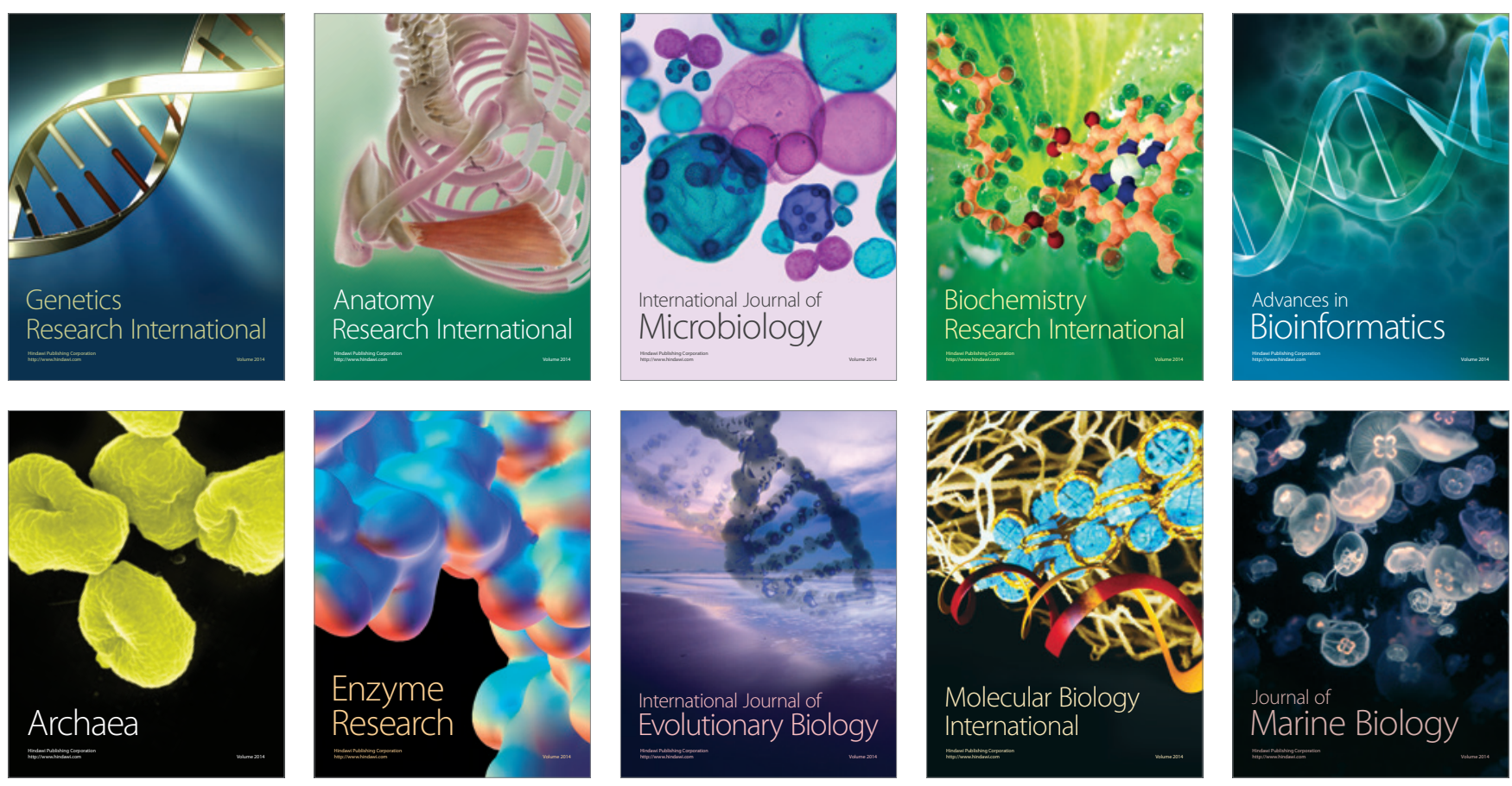